Acta vet. scand. $1976,17,441-450$.

From the Department of Microbiology and Immunology, Veterinary College of Norway, Oslo.

\title{
SINGLE CELL PROTEIN IN THE DIETS OF PIGS AND CHICKENS
}

\section{EFFECTS ON THE ACTIVITY OF DNASE IN INTESTINAL CONTENTS}

By

Eivind Liven and Kristian Staveland

LIVEN, E. and K. STAVELAND: Single cell protein in the diets of pigs and chickens. Effects on the activity of DNase in intestinal contents. Acta vet. scand. 1976, 17, 441-450. - Pigs and chickens were fed diets containing increased concentrations of the single cell protein (SCP), Pruteen, in order to investigate the effects of a diet containing high levels of nucleic acids on the activity of DNase in intestinal contents. Increased levels of SCP in the diet generally resulted in increased DNase activity in intestinal contents.

Significant differences at $\mathrm{P} \leqq 0.05$, were found between the control groups and most of the experimental groups in both species.

With the exception of the 2 groups given the highest levels of SCP in the chicken experiment, the DNases in the large intestines were not inhibited by antisera produced against DNase in pancreatic juice.

single cell protein; deoxyribonucleases;

intestinal content.

The diet can influence the amounts of enzymes in the intestinal tract. Thus, Bell et al. (1968) found that the concentrations of proteinases, amylases and lipases in pancreatic juice varied, depending on the concentrations of the substrates in the diet to which the animal was accustomed. In addition the content of enzyme inhibitors in the diet can influence the production of digestive enzymes (Richard \& Lepkovsky 1957). The concentration of nucleic acids (NA) in single cell protein (SCP) is high compared with conventional foodstuffs (Kihlberg 1972). However, little information seems to exist on the activity of pancreatic nucleases related to the amount of ingested substrate. 
Among domestic animals, poultry has a metabolism by which uric acid is produced from the purine bases in the NA. In man the metabolic pattern is the same. In other animals, the uric acid is converted to allantoin, a metabolite which has not been shown to have any disease-provoking ability. Uric acid, however, is connected with pathological conditions both in man and poultry. With this background, a study of the effect of SCP on the activity of DNase in intestinal contents would be of special interest. Hazards due to excessive intakes of NA have also been discusised for other animals than poultry (Kihlberg).

The aim of the present work was to study the activity of deoxyribonucleases (DNases) in different parts of the intestinal tract, and to gather information on their origin in pigs and chickens fed SCP in various concentrations compared to animals fed conventional diets.

\section{MATERIALS AND METHODS}

\section{Experimental animals}

Twenty-seven weaned, randomly selected, Norwegian Landrace pigs and 401 day-old female chickens of the White Italian breed, selected for uniform weight, were each divided into 4 groups. Group 1 represented the control group and groups 2, 3 and 4 the experimental groups.

Each group of the pigs consisted of 7 animals, with the exception of group 4 which numbered 6 animals. The chicken groups had 10 animals in each group. The pigs were slaughtered at a weight of $90 \mathrm{~kg}$, and the chickens at an age of 66 days.

\section{Diet composition}

Corresponding to the group number, the diets are designated 1, 2, 3 and 4. The SCP used in this experiment is named Pruteen * and is a product of a strain of Pseudomonas methylotropha grown on a substrate containing methanol as the carbon and energy source (Roth \& Kirchgessner 1976). The content of NA in Pruteen is about $16 \%$ (Gow et al. 1974). In diet 1, the protein originated from soya, wheat, maize and oats. In diets 2 and 3 the soya protein was partially substituted with SCP. In diet 4 exces-

\footnotetext{
* Imperial Chemical Industries Limited (ICI).
} 
sive amounts of SCP compared to the other diets were used. Table 1 presents the percentage and origin of crude protein in the various diets.

Further details about diet composition are given by Farstad (in press).

Table 1. The source of crude protein (in per cent) and the total amount of crude protein in the various diets.

\begin{tabular}{|c|c|c|c|c|c|c|c|c|}
\hline \multirow[b]{2}{*}{ Diet } & \multicolumn{4}{|c|}{$\begin{array}{l}\text { Percentage of crude protein in } \\
\text { the diets of pigs }\end{array}$} & \multicolumn{4}{|c|}{$\begin{array}{l}\text { Percentage of crude protein in } \\
\text { the diets of chickens }\end{array}$} \\
\hline & SCP & soya & OPS* & tot. protein & SCP & soya & OPS & tot. protein \\
\hline 1 & 0 & 7.4 & 8.0 & 15.4 & 0 & 11.0 & 7.2 & 18.2 \\
\hline 2 & 3.6 & 3.4 & 8.4 & 15.4 & 4.8 & 5.5 & 7.7 & 18.0 \\
\hline 3 & 6.9 & 0 & 8.7 & 15.6 & 9.7 & 0 & 8.3 & 18.0 \\
\hline 4 & 19.3 & 0 & 8.2 & 27.5 & 19.5 & 0 & 7.1 & 26.6 \\
\hline
\end{tabular}

* Other protein sources than SCP and soya.

\section{Intestinal contents}

Pig intestinal contents from the duodenum, upper-, middleand the lower middle part of the jejunum, from the middle part of the colon and from the rectum were collected. Chicken intestinal contents were taken from the duodenum/jejunum, caecum and colon. Intestinal contents were prepared as described by Liven (1976).

\section{Measurement of DNase activity}

The DNase activity in the intestinal contents was measured using toluidine blue deoxyribonucleic acid agar (TDA) (Lachica et al. 1971) as described by Liven.

\section{Antisera against pancreatic DNases}

Antisera against the protein fraction of pig and chicken pancreas tissue were produced in rabbits. The antigen was prepared by homogenizing equal amounts of pancreas tissue and saline, after which the solution was centrifuged at $9000 \times \mathrm{g}$ for $15 \mathrm{~min}$. The supernatant was added $\left(\mathrm{NH}_{4}\right)_{2} \mathrm{SO}_{4}$ to $80 \%$ saturation and the precipitate dialyzed against running tap water for $18 \mathrm{hrs}$. The dialyzed solution was concentrated to $1 / 3$ of its original volume using aquacide as a water-extracting agent. This material was mixed with equal amounts of Freunds adjuvant (Difco), and 
5 injections of $1.0-2.0 \mathrm{ml}$ i.c. were given at 1 to 2 week-intervals. Freunds complete adjuvant was used in the first injection. Freunds incomplete adjuvant was used in the following injections. The rabbits were bled 2 weeks after the last injection.

Before the commencement of the immunizing procedure the rabbit sera were tested for naturally occurring antienzymes towards pancreatic DNases.

\section{Testing of antisera and demonstration of pancreatic DNase activity in intestinal contents}

For the testing of antisera against pancreatic DNases and for the serological examination of the DNase activity in intestinal contents, $3 \mathrm{~mm}$-wide filter paper strips moistened with antienzyme were placed on the TDA surface and left there for $3 \mathrm{hrs}$. at $37^{\circ} \mathrm{C}$. After removal of these strips, similar strips moistened with the protein fraction from pig- and chicken pancreas tissue, or intestinal contents were laid on the surface of the agar at right angles to the direction of application of antienzymes. At low DNase activity, intestinal contents were applied into $2 \mathrm{~mm}$-wide troughs in the TDA.

Interruption or narrowing of the pink zones in the TDA due to DNase activity in the pancreatic extract indicated the presence of antienzymes in the sera. Similarly, inhibition of DNase activity in intestinal contents by the antisera was taken as an indication of pancreatic origin of the DNases.

\section{RESULTS}

Fig. 1 shows the DNase activity in the various parts of the intestinal tract from the 4 groups of pigs and the 4 groups of chickens expressed in diffusion units.

Compared with the control group, the DNase activities in the experimental groups were generally increased in the various parts of the intestine. In group 2 reduced DNase activity, compared with the control, was found in the duodenum/jejunum of the chickens and from the upper part of the jejunum of the pigs. Otherwise, the DNase activity in group 2 was slightly elevated compared with the control. In group 3, the activity was considerably increased compared with the control group as well as with group 2. This increase was large especially in the pigs and in 

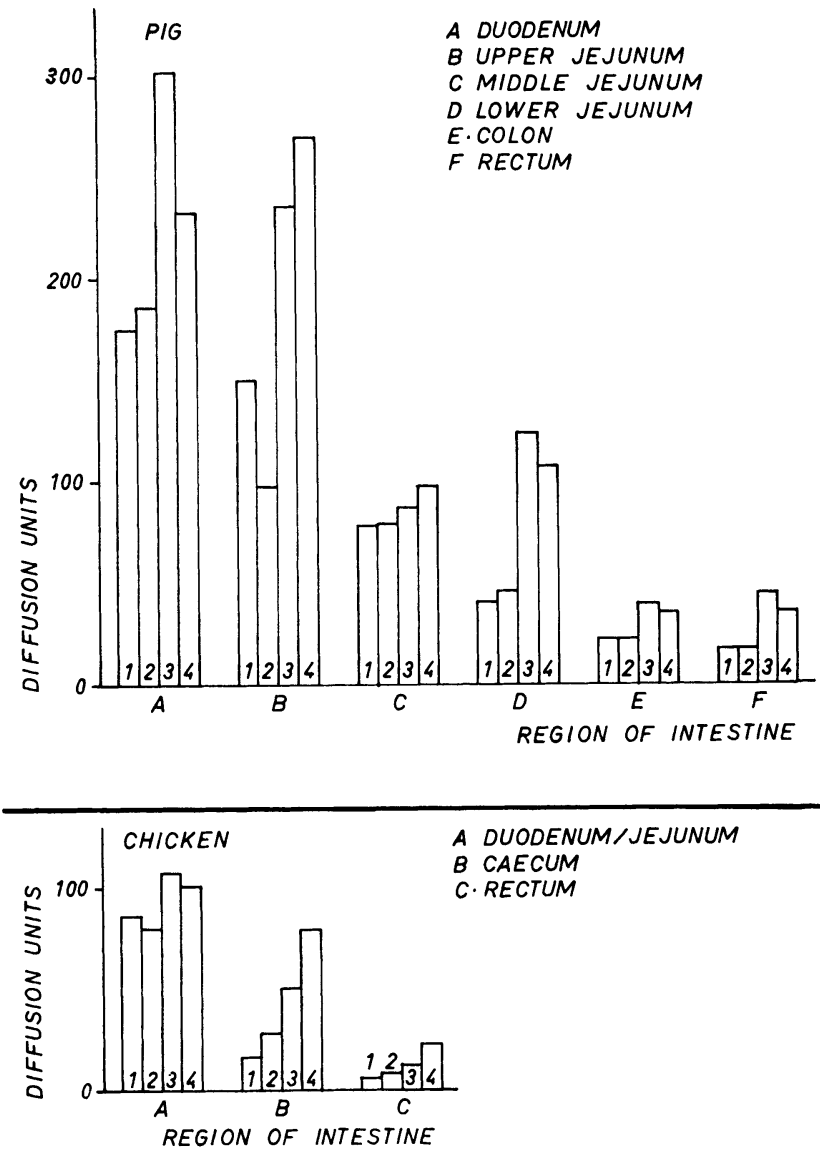

F i gur e 1. Average DNase activity expressed in diffusion units in intestinal contents from various regions (A, B, C, D, E, F) of the intestinal tracts of pigs and chickens in the different groups $(1,2,3,4)$.

some parts of the intestine amounted to a doubling. In group 4 the DNase activity was more or less similar to group 3. Only in the samples from caecum and rectum in the chickens the increase in group 4 was obvious.

Generally the DNase activity both in pigs and chickens reached the highest levels in the upper part of the intestinal tract and was reduced thereafter.

The differences in DNase activities between the groups were statistically analyzed. Table 2 presents the results of these analyses. 
Table 2. Statistical differences of DNase activity $(P \leqq 0.05)$ in different regions of the intestinal tract in the various groups of pigs and chickens. Figures in brackets indicate the groups between which significant differences were found.

\begin{tabular}{lcc}
\hline Part of the intestine & Pigs & Chickens \\
\hline duodenum/jejunum & $+^{1}$ & - \\
caecum & $\mathrm{x}$ & $+^{2}$ \\
colon & $+^{3}$ & $\mathrm{x}$ \\
rectum & $+^{4}$ & $+^{5}$ \\
\hline
\end{tabular}

-: No significance $(P \geqq 0.05)$

$+:$ Significance $(P \leqq 0.05)$

$\mathrm{x}$ : No samples collected

1 : $(1-3,2-3)$

$2:(1-3,1-4,2-4,3-4)$

$3:(1-3,2-3)$

$4:(1-3,1-4,2-3,2-4)$

$5:(1 \longrightarrow 4,2-4,3 \longrightarrow 4)$

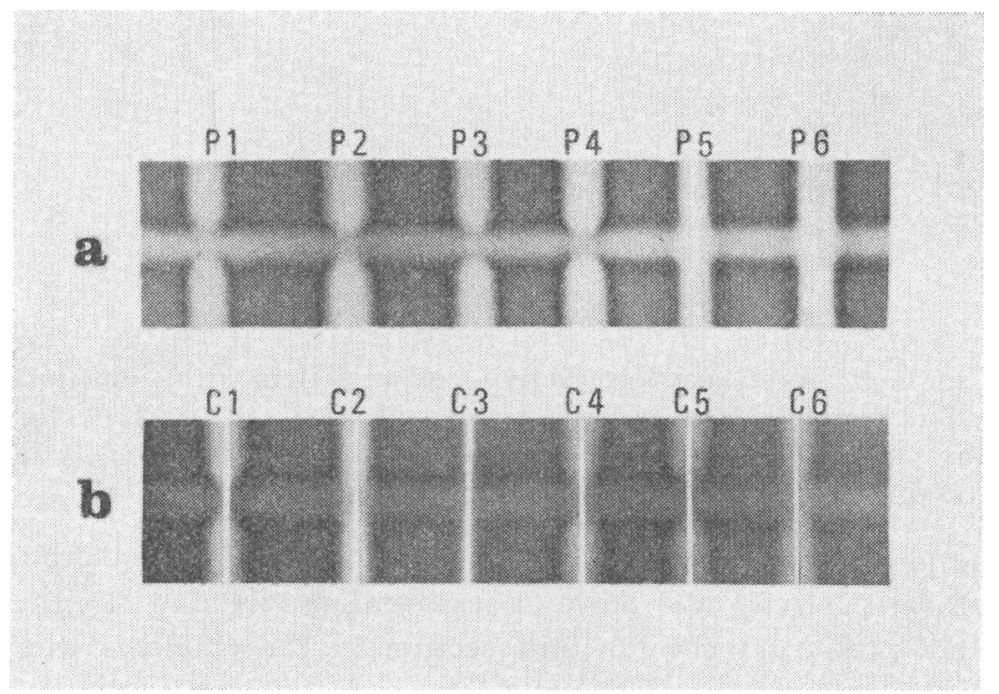

F i g u r e 2. Inhibition of DNase activity in intestinal content (P1P6, C1 - C6) by antienzymes against pancreatic DNases from pigs (a) and chickens (b). The origin of intestinal contents is as follows: P1P6: duodenum, upper, middle and lower jejunum, colon and rectum from pig. C1-C3: duodenum/jejunum, caecum and rectum from chicken group 1, C4- 6 6: duodenum/jejunum, caecum and rectum from chicken group 4 . 
Fig. 2 shows the effect of antienzymes against pancreatic DNase on the DNases in the intestinal contents from various parts of the intestine of pigs and chickens. In the pigs, intestinal DNases were inhibited by the antienzymes in all parts of the small intestine. In the large intestine inhibition of DNases was never demonstrated.

Small intestinal DNase activity from the chickens was also inhibited by antienzymes against pancreatic DNases in all groups. In groups 1 and 2 the DNase activity in the large intestine was not inhibited. In group 3 large intestinal DNases were frequently inhibited, while in group 4 inhibition of the DNase activity was constantly present.

\section{DISCUSSION}

Increased concentrations of Pruteen in the diet in this experiment usually induced increased concentrations of DNases in the intestinal contents both in pigs and chickens. In contrast to the pigs, the chickens also showed DNases of pancreatic origin in the large intestine in groups 3 and 4.

As presented in Table 2 some of the differences between the groups compared were not significant at $\mathrm{P} \leqq 0.05$. In a similar experiment performed by Reboud et al. (1962) the effects of elevated concentrations of casein, starch and fat in the diet on the activities of the corresponding enzymes in homogenates of pancreas from rats were measured. These authors found a 2-fold increase in the activity of some enzymes when compared with conventional diets. Thus it seems justified to consider the differences in DNase activity between some groups in the present experiment as considerable, although Pruteen has an approx. 8-fold increase in NA concentration compared with conventional foodstuffs.

In the present experiment the difference in SCP concentration in the diets between groups 3 and 4, which amounts to $100 \%$, did not bring about any general increase in DNase concentration in the intestinal contents. In both species, and particularly among the pigs, a reduction of the DNase activity compared with group 3 was found. This phenomenon could indicate that the substrate concentration in diet 4 had reached a level at which higher substrate concentrations no longer stimulated enzyme production.

With few exceptions, the antisera employed gave no inhibition of the DNase activity in the large intestine. This could indi- 
cate that pancreatic DNases were absent in this part of the intestinal tract. The most probable extra-pancreatic source of the DNases could be organisms belonging to Bacteroidaceae which constitute a large part of the large interestinal flora, and also are known to produce DNases (Porschen \& Sonntag 1974). However, Liven (1976) showed that in pigs fed conventional diets, some DNases were found, also in the large intestine, which, according to zymograms, were similar to those found in the small intestine and in pancreas homogenates. In addition, in the large intestine and in the lower parts of the small intestine, DNase activity was demonstrated which was not found in pancreas homogenates. Consequently, it is likely that also in this experiment pancreatic DNases were present to some extent in the large intestine. The reason why the pancreatic DNases were not demonstrated by the method used might be that other DNases (microbial) were present in higher amounts thus concealing the first ones. In addition, a possible change in the antigenic structure of the DNase molecule through the intestinal tract by proteinases or other factors cannot be excluded. The DNase avtivity declined regularly backwards in the small intestine. As regards proteinases, amylases and lipases, however, Fossum \& Liven (1974) generally found the same level of enzyme activity in the upper and lower part of the small intestine.

This reduced DNase activity is probably brought about by proteolytic enzymes, but it may as well be due to DNase inhibitors. The presence of DNase inhibitors has been demonstrated in various kinds of tissue and also from the intestinal mucosa (Cooper et al. 1950). An inhibitory effect of intestinal contents against DNases both of microbial and animal origin has also been demonstrated recently (Liven unpublished).

This investigation has shown that elevated concentrations of SCP in the diet generally result in increased DNase activity in the intestinal tract. Whether the increase in DNase activity combined with the large amounts of $\mathrm{NA}$ in the diet results in higher plasma levels of NA-metabolites has not been examined. However, the possibility of toxic effects, especially in poultry, should not be excluded. A question of considerable importance is also whether the increased DNase activity in the intestinal content has any influence on microbial DNA. 


\section{REFERENCES}

Bell, G. H., J. N. Davidson \& H. Scarborough: Textbook of Physiology and Biochemistry. E. \& S. Livingstone LTD, Edinburgh and London 1968.

Cooper, E. J., M. L. Trautmann \& M. Laskowski: Occurrence and distribution of an inhibitor for deoxyribonuclease in animal tissues. Proc. Soc. exp. Biol. (N.Y) 1950, 73, 219—222.

Farstad, L.: Biological effects of feeding single cell protein produced by Pseudomonas methylotropha from methanol to chickens. Acta agric. scand. (In press).

Fossum, K. \& E. Liven: The distribution of enzymes and bacteria in the small intestines of slaughter pigs. Acta path. microbiol. scand. Sect. B. 1974, 82, 644-652.

Gow, J. S., J. D. Littlehailes, S. R. L. Smith \& F. B. Walter: Single cell protein from methanol: The development of the ICI process. In S. R. Tannenbaum \& D. J. C. Wang (eds.) : Proc. 2nd Int. Conf. Single Cell Protein. May 29—31, 1973. M.I.T., Cambridge, Mass. 1974.

Kihlberg, R.: The microbe as a source of food. Ann. Rev. Microbiol. $1972,26,427-466$.

Lachica, R. V. F., G. Genigeorgis \& P. O. Hoeprich: Metachromatic agar-diffusion methods for detecting Staphylococcal nuclease activity. Appl. Microbiol. 1971, 21, 585—587.

Liven, E.: The applicability of agar-diffusion test in measuring deoxyribonucleases in pig intestinal content. Acta vet. scand. 1976, $17,244-254$.

Porschen, R. K. \& S. Sonntag: Extracellular deoxyribonuclease production by anaerobic bacteria. Appl. Microbiol 1974, 27, 10311033.

Reboud, J. P., A. Ben Abdeljlil \& P. Desnuelle: Variations de la teneur en enzymes du pancréas de rat en function de la composition des régimes. (Variation of the enzymic content of rat pancreas as a function of the composition of the diet). Biochim. biophys. Acta (Amst.) 1962, 58, 326-337.

Richard, L. L. \& S. Lepkovsky: The effect of raw soybean meal and trypsin inhibitor diets on pancreatic enzyme secretion in the rat. J. Nutr. 1957, $62,269-284$.

Roth, F.X. \& M. Kirchgessner: Methanol-fermentation protein in veal calf nutrition. Animal Feed Sci. Technol. 1976, 1, 33-44.

\section{SAMMENDRAG}

Virkningen av encelleprotein $i$ fóret til gris og kylling på DNase aktiviteten $i$ tarminnholdet.

Griser og kyllinger ble gitt $\emptyset$ kende konsentrasjoner encelleprotein, Pruteen, for å unders $\varnothing \mathrm{ke}$ virkningen av et fór som inneholdt h $\phi y$ e konsentrasjoner nukleinsyre. Økende mengder encelleprotein i fóret resulterte generelt $i$ for $\varnothing$ ket DNase aktivitet $i$ tarminnholdet. 
Mellom kontrolgruppene og de fleste fors $\varnothing$ ksgrupper ble det påvist signifikante forskjeller $(P \leqq 0.05)$ hos begge arter.

Med unntak av de 2 kyllinggrupper som fikk de høyeste konsentrasjoner encelleprotein, ble DNasene i tykktarmen ikke hemmet av antisera som ble produsert mot DNaser i pancreassekretet.

(Received September 27, 1976).

Reprints may be requested from: Eivind Liven, Department of Microbiology and Immunology, Veterinary College of Norway, P. O. Box 8146, Oslo Dep., Oslo 1, Norway. 